\title{
DNA BARCODING OF THE FAMILY PHRYGANEIDAE (INSECTA, TRICHOPTERA) IN CROATIA WITH PARTICULAR REFERENCE TO PHYLOGENY, DISTRIBUTION AND CONSERVATION BIOLOGY
}

\author{
Mladen Kučinićí ${ }^{*}$, Angela Ćukušić ${ }^{2}$, Darko Cerjanec ${ }^{3}$, Martina \\ Podnar $^{4}$, Mladen Plantak ${ }^{5}$, Sanja Žalac ${ }^{6}$, Renata ĆuK ${ }^{7}$, Ivan VučKović ${ }^{5}$, \\ Halil Ibrahimi $^{8}$ \& Antun Delić ${ }^{9}$ \\ ${ }^{1}$ Department of Biology (Laboratory for Entomology), Faculty of Science, University of Zagreb, Rooseveltov \\ $\operatorname{trg}$ 6, 10000 Zagreb, Croatia \\ ${ }^{2}$ Croatian Ministry of Potection of Nature and Energetic, Radnička cesta 80/7, 10000 Zagreb, Croatia \\ ${ }^{3}$ Primary school Barilović, Barilović 96,47252 Barilović, Croatia \\ ${ }^{4}$ Croatian Natural History Museum, Demetrova 1, 10000 Zagreb, Croatia \\ ${ }^{5}$ Elektroprojekt d.d., Civil and Architectural Engineering Department, Water Resources, Nature and \\ Environmental protection, Alexandera von Humboldta 4, 10000 Zagreb, Croatia \\ ${ }^{6}$ ZSC „Dr. Ivo Pevalek“, National park Plitvice Lakes, Josipa Jovića 19, 53231 Plitvička jezera, Croatia \\ ${ }^{7}$ Hrvatske vode, Ulica grada Vukovara 220, 10000 Zagreb, Hrvatska 10000 Zagreb, Croatia \\ ${ }^{8}$ Department of Biology, Faculty of Mathematics and Natural Sciences, University of Prishtina, Mother \\ Theresa p.n., 10000 Prishtina, Kosovo \\ ${ }^{9}$ Nikole Šubića Zrinskog 3, 43290 Grubišno Polje, Croatia
}

Kučinić, M., Ćukušić, A., Cerjanec, D., Podnar, M., Plantak, M., Žalac, S., Ćuk, R., Vučković, I., Ibrahimi, H. \& Delić, A.: DNA barcoding of the family Phryganeidae (Insecta, Trichoptera) in Croatia with particular reference to phylogeny, distribution and conservation biology. Nat. Croat., Vol. 28, No. 2., 305-323, 2019, Zagreb.

In Europe the Phryganeidae family comprises 7 genera and 20 species. In Croatia, 6 species have been recorded from this family, and four of them recorded and collected in the last five years have been DNA barcoded. In terms of faunistic research, most interesting is the record of Trichostegia minor Curtis, 1834 from the region of the Gacka River in Lika, in upland Croatia. Up to now four species have been included in the BOLD system with 6 DNA-barcoded specimens. From the Gacka River area, 11 specimens of 8 species, including T. minor, have been barcoded and included into the BOLD system. Phylogenetic research based on DNA barcode data has shown some interesting results. Specimen of T. minor collected in the area of the Gacka River is clustered with a specimen of this species from Austria into a separate subgroup, which shows minor molecular specifics. Phylogenetic analysis has confirmed the justification of the status of a subspecies from Mongolia, Phryganea grandis rotundata Ulmer, 1905.

Future Trichoptera fauna research in Croatia will continue investigations of the family Phryganeidae in various parts of the country for the purpose of ascertaining the detailed distribution of all the species recorded, to enable finding some other previously missing species, as well as collecting and DNA barcoding of Hagenella clathrata (Kolenati, 1848) and Oligostomis reticulata (Linnaeus, 1761). With respect to these species, the data will also be useful for the area of conservation biology, necessary for their protection and for the protection of the sites in which they occur, for it is clear that these are very rare species in Croatia, T. minor also belonging to this group: $50 \%$ of the species from this family recorded in Croatia are rare and very rare species.

Key words: COI, Phryganea grandis rotundata, Trichostegia minor, south-east Europe, dinaric karst, the River Gacka 
Kučinić, M., Ćukušić, A., Cerjanec, D., Podnar, M., Plantak, M., Žalac, S., Ćuk, R., Vučković, I., Ibrahimi, H. \& Delić, A.: DNA barkodiranje porodice Phryganeidae (Insecta, Trichoptera) u Hrvatskoj, s posebnim osvrtom na filogeniju, rasprostranjenost i konzervacijsku biologiju. Nat. Croat., Vol. 28, No. 2., 305-323, 2019, Zagreb.

Porodica Phryganeidae broji u Europi 7 rodova i 20 vrsta. Iz ove porodice na području Hrvatske utvrđeno je 6 vrsta, od kojih su DNA barkodirane četiri vrste, zabilježene i prikupljene u posljednjih pet godina. Faunistički najzanimljiviji je nalaz vrste Trichostegia minor Curtis, 1834 s područja rijeke Gacke (regija Lika), gorska Hrvatska. U BOLD bazu upisane su četiri vrste sa šest DNA barkodiranih primjeraka. S područja rijeke Gacke je DNA barkodirano i upisano u BOLD bazu 11 primjeraka s osam vrsta, uključujući i vrstu T. minor. Filogenetska istraživanja temeljena na analizi DNA barkod podataka pokazala su zanimljive rezultate. Primjerak vrste T. minor prikupljen na području rijeke Gacke grupira se s primjerkom te vrste iz Austrije u zasebnu podgrupu, što ukazuje na manje molekularne specifičnosti. Filogenetska analiza potvrdila je i opravdanost statusa podvrste iz Mongolije, Phryganea grandis rotundata Ulmer, 1905.

U budućim istraživanjima faune Trichoptera Hrvatske nastavit će se istraživanja porodice Phryganeidae $\mathrm{u}$ različitim dijelovima Hrvatske u svrhu utvrđivanja detaljnijeg rasprostranjenja svih zabilježenih vrsta, potencijalnog nalaza neke još nezabilježene vrste, ali i nalaza te DNA barkodiranja vrsta Hagenella clathrata (Kolenati, 1848) i Oligostomis reticulata (Linnaeus, 1761). Za te vrste bit će potrebno utvrditi i određene značajke u području konzervacijske biologije potrebne za njihovu zaštitu i zaštitu lokaliteta na kojima žive, jer je očito da su to vrlo rijetke vrste u fauni Hrvatske, u koje pripada i vrsta T. minor; naime, 50\% zabilježenih vrsta porodice Phryganeidae u Hrvatskoj su rijetke ili vrlo rijetke vrste.

Ključne riječi: COI, Phryganea grandis rotundata, Trichostegia minor, jugoistočna Europa, dinarski krš, rijeka Gacka

\section{INTRODUCTION}

The family Phryganeidae belongs to the order Trichoptera, superfamily Phryganeoidea suborder Integripalpia. The superfamily Phryganeoidea includes 7 families: Baissoferidae, Dysoneuridae, Kalophryganeidae, Kokiriidae, Lepidostomatidae, Oeconesidae and Phryganeidae, the first three of which are extinct (Morse, 2019). The family Phryganeidae is a not very species-rich family of Trichoptera, with about 80 described species in 15 genera (Holzenthal et al., 2007). In Europe there are seven genera and 20 described species (MaLickY, 2004). Lot of species have adults with large or very large forewings, $20 \mathrm{~mm}$ or more, for example Phryganea grandis Linnaeus, 1758 or Agrypnia varia (Fabricius, 1793) (Malicky, 2004). The genus Eubasilissa from this family includes the largest species of caddisflies (Holzenthal et al., 2007). Larvae from family Phryganeidae produce long, spiral or ring cases from parts of plants (stems), sometimes with small pebbles. The family is distributed in the Palearctic, Nearctic and Holacrtic regions (Holzenthal et al., 2007).

This paper consists of (1) a depiction of the distribution and biodiversity of family Phryganeidae in Croatia, with a reference to the rare species Trichostegia minor (Curtis, 1834); (2) DNA barcode data and a phylogenetic depiction of the family Phryganeidae as compared with other genera and species included in the list of barcoded Trichoptera from Croatia; (3) faunistic features of the Trichoptera fauna of the Gacka River where some interesting species of the family Phryganeidae were collected, including T. minor together with a presentation of the DNA barcoded specimens and species collected from this area included in the BOLD database. 
The study of the Earth's biodiversity is a very long process that started with the development of humankind and attained scientific dimensions with the establishment of binomial nomenclature, the taxonomic, and the basic evolutionary model for the depiction of this diversity (LinnaEus, 1758). Since this period (the $18^{\text {th }}$ century), and according to this model and the rules of taxonomy (for example, the ICZN 2000), a large number of organisms on Earth have been described, with more than a million known species, which is considered as just a part of total existing biodiversity. Each year thousands of new species within various groups of organisms are described (for example BREHM et al., 2019; DA Silva et al., 2014; Fang \& XING, 2019; Malicky, 2017; Suwannarat et al., 2019; ViteCEK et al., 2015c; YÁNez-MuÑoz et al., 2018) which leads to further knowledge of biodiversity on Earth. Such a model of describing new species using primarily a morphological approach and an analysis of morphological features of organisms was significantly changed when the DNA barcoding method was discovered and began to be applied (Hebert et al., 2003a, 2003b). DNA barcoding and other molecular analyses made it possible to study biodiversity, taxonomy and phyologeny not only based on the morphological, but also on the genetic level (DAYRAT, 2005). The employment of morphological and genetic methods made possible the development of what is called integrative taxonomy (for example, Bilandžija et al., 2013., Bogdanović et al., 2014, 2019; Dayrat, 2005; IвRAhimi et al., 2016; ViteceK et al., 2017; Will et al., 2005), which is much more comprehensive, for it involves various morphological and genetic analyses and enables the taxonomic, phylogenetic, phylogeographic and biogeographic features of any given taxon or group of organisms to be established much more accurately. In the last 15 years, DNA barcoding has become one of the essential methods in taxonomy, phylogeny, and phylogeography (for example, Geraci et al., 2011; Hjalmarsson et al., 2019; Kučinić et al., 2015; Pauls et al., 2010; Pfeiler, 2018; ViteceK et al., 2015a, 2015b; Will et al. 2005). As well as DNA barcoding, which analyses a certain segment of mitochondrial DNA, there are other kinds of genetic analysis that involve other genes which makes possible a further and better quality presentation of the evolutionary process and the taxonomic and phylogenetic position of certain taxa (for examples Pauls et al., 2006, 2009; Previšrć et al., 2009, 2014; VITECEK et al., 2017).

The DNA barcoding method is used in Trichoptera taxonomy and phylogeny in various regions of the world and in the last few years has been used in caddisfly research in Croatia as well (Ćukušrć et al., 2017; Kučinić et al. 2013; Szivák et al., 2017). Systematic implementation of DNA barcoding of Trichoptera in Croatia started with the studies of e.g. Kučinić et al. (2013) and has lasted with larger or smaller lacunae to this day (Ćukušić et al., 2017; Kučinić, 2019). Currently the ongoing scientific project "DNA barcoding of faunal biodiversity in Croatia“ has placed the Trichoptera as one of the target groups. The present paper is a part of this scientific project. 


\section{MATERIAL AND METHODS}

\section{Field work}

The sampling of Trichoptera for DNA barcoding was conducted during the last few years in various parts of Croatia (Pannonian and Peri-Pannonian part, central-mountain part and Mediterranean part) (Fig. 1), including the area of the Gacka River (2012, 2015, 2016) (Fig. 2) and the Kostelka River (in 2019). These rivers are situated in the central-mountain part of Croatia, in a Dinaric karst region called Lika (BERTić et al., 2001). The sampling at the Gacka River included four sites: Tonkovića vrilo (spring), Majerovo vrilo (spring), Sinac vrilo (spring) and the middle course of the Gacka River near Otočac and at the spring of the Kostelka River. The Gacka River has three main springs: Majerovo vrilo, Sinac vrilo and Tonkovića vrilo.

Trichoptera were collected with an entomological net for a period of 30 minutes (i.e., the time that a single work effort lasted) and at night with $12 \mathrm{~V}$ UV lamps and a portable battery for a period of 60 minutes.

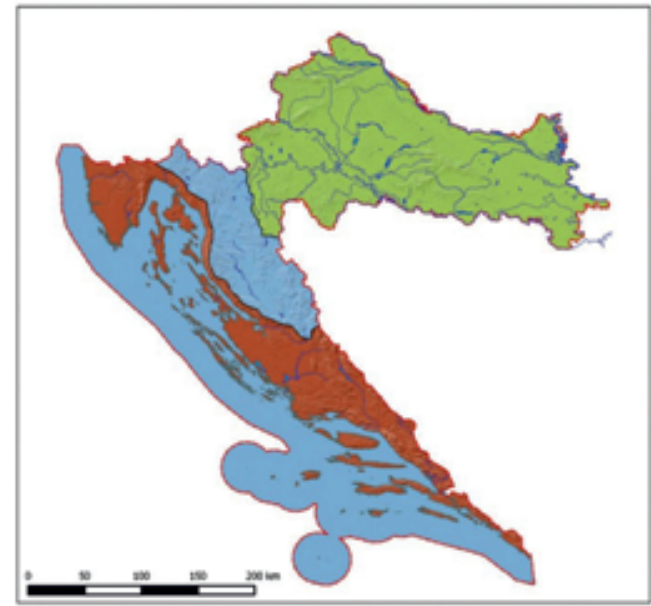

Fig. 1. Map of Croatia with three geographical parts: Pannonian and Peri-Pannonian part (green), Central-mountain part (i.e. upland part; blue) and Mediterranean part (red); according to BERTić et al. (2001).

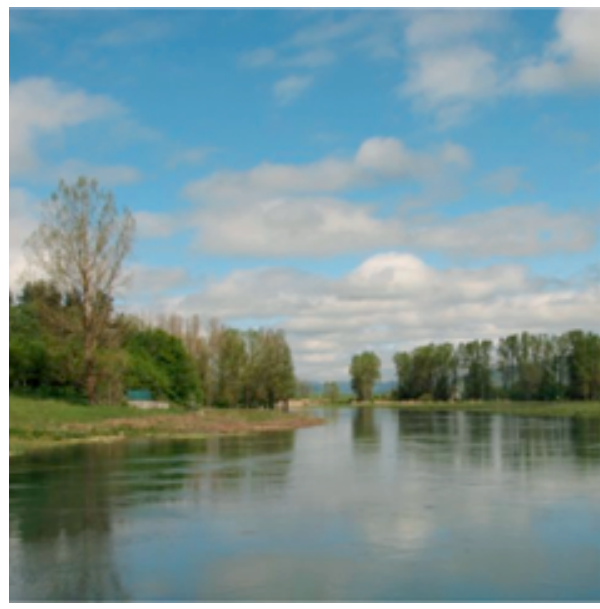

Fig. 2. Middle part of the River Gacka, near the town of Otočac (photo M. Vuković).

\section{Laboratory work}

All the collected Trichoptera material was preserved in pure ethanol. Determination of the material was conducted after MALICKY (2004) and KumANSKI (1988), and a systematic presentation after Morse (2019) is provided. The material collected is a component part of the NIP Trichoptera Collection (Croatian Natural History Museum, Zagreb) and the Cerjanec Trichoptera Collection. DNA barcoded specimens collected from the area of the Gacka River are kept as vouchers in the Croatian Natural History Museum in Zagreb. Literature data (MARINKovićGospodnetić, 1979) are also used in the presentation of the Trichoptera fauna of the Gacka River. 
Macrophotographing of Trichoptera adults was carried out using a Leica Wild MZ8 stereomicroscope and Olympus SP-500 UZ digital camera, processed with the computer program Olympus Quick Photo Camera 2.2 at the Laboratory for patology of trees (Department of Forest Protection and Wildlife Management) at the Faculty of Forestry, University of Zagreb.

\section{DNA extraction, PCR amplification and phylogenetic analysis}

Genomic DNA was extracted from legs of four specimens, one T. minor and the other caddisfly species listed in Appendix 1 with specimen IDs marked with bold letters. All specimens are kept as vouchers in the Trichoptera DNA Barcode collection in the Croatian Natural History Museum in Zagreb. Genomic DNA was extracted using GenElute Mammalian Genomic DNA Miniprep kit (SigmaAldrich, Germany) according to the manufacturer's specifications and eluted in 50 $\mu \mathrm{l}$ of elution buffer. For the amplification of the COI-5P, barcode region primers LCO1490 and HCO2198 (C 1994) were used. The volume of mixture for polymerase chain reactions (PCR) was $50 \mu \mathrm{l}$. The PCR mixture contained 1 x Go Taq®Reaction Buffer (containing $1.5 \mathrm{mM} \mathrm{MgCl2}$, Promega), $0.2 \mathrm{mM}$ of each dNTP, $0.4 \mu \mathrm{M}$ of each primer, 1.25 units of Go Taq ${ }^{\circledR}$ DNA Polymerase (Promega) and $5 \mu$ l of DNA eluate. PCR cycling conditions comprised an initial denaturation step $\left(94^{\circ} \mathrm{C}\right.$ for 2 min) followed by 35 cycles of denaturation at $94^{\circ} \mathrm{C}$ for $30 \mathrm{~s}$, annealing at $50^{\circ} \mathrm{C}$ for $30 \mathrm{~s}$ and elongation at $72^{\circ} \mathrm{C}$ for $90 \mathrm{~s}$ and a final extension step of $72^{\circ} \mathrm{C}$ for $7 \mathrm{~min}$. Product purification and bidirectional sequencing was performed by Macrogen Inc. sequencing service (Seoul, South Korea) using the amplification primers. Sequences were edited manually and aligned using the program BioEdit (HALL, 1999).

For phylogenetic analysis, all available barcode sequences from family Phryganeidae were retrived from the BOLD System database (BOLD IDs are given in Appendix 1). DNA sequences obtained in this study were submitted to Barcode of Life Data Systems (BOLD, Ratnasingham \& Hebert 2007, Appendix 1, Tabs. 2 and 4). As outgroup taxon Lepidostoma hirtum (Fabricius, 1775) was selected (Appendix 1) which belongs to the same superfamily Phryganeoidea WE Leach, 1815. Indistinguishable sequences were collapsed into unique haplotypes using FaBox v.1.41 (Villesen, 2007). All haplotypes are listed in Appendix 1, Tabs. 2 and 4. Two different methods of tree reconstruction were used: Neighbor-Joining (NJ) and Maximum likelihood (ML) as implemented in MEGA 7.0. (KumAr et al., 2016) to infer phylogeny-based specimen identification. Details of phylogenetic analyses were performed as outlined by ĆuKušić et al. (2017).

Inter- and intraspecific genetic uncorrected pairwise divergences ( $p$ - distances) were calculated in MEGA 7.0. (Kumar et al., 2016). The number of hypothetical species within a data set was estimated based on barcode gap (difference between inter- and intraspecific genetic distances) by using Automatic Barcode Gap Discovery, ABGD (Puillandre et al., 2012). The mtCOI data set was submitted to the ABGD online website using the following settings: $\mathrm{P}$ (prior intraspecific divergence) set from 0.001 (Pmin) to 0.08 (Pmax) and Steps set to 10; X (minimum relative gap width) set to 1 ; $\mathrm{Nb}$ bins (for distance distribution) set to 20; we selected the Kimura (K80) model and set TS/TV to 2.0. 


\section{RESULTS AND DISCUSSION}

Biodiversity, distribution and some aspects of the conservation of Phryganeidae in Croatia Six species from five genera of Phryganeidae are recorded in Croatia (Tab. 1). Three species were reported for the first time in the Plitvice Lakes National Park (KučInIć, 2002): Agrypnia varia, Phryganea bipunctata Retzius, 1783 and P. grandis. Hagenella clathrata (Kolenati, 1848) was first found around Zagreb (Radovanović, 1935) and subsequently in central Croatia (Previšić et al., 2013). Oligostomis reticulata (Linnaeus, 1761) was discovered at the spring of the Kostelka River (Marinković-Gospodnetić, 1979) and Trichostegia minor was established in northern Croatia only 89 years ago (leg. F. Košćec) (MaLICKY, 2009).

The number of recorded species indicates the relatively good state of research of this family in Croatia; one or two more species can be expected in Croatia based on the situation in well-researched neighbouring areas. In Slovenia, Italy and Hungary, for example, eight species of this family have been recorded (Cianficconi, 2002; Krušnik \& Urbanič, 2002; Nógardi \& Uherkovich, 2002).

In terms of species, $83 \%$ ( 5 species) of the Phryganeidae family have been found in the Pannonian and Peri-Pannonian as well as in the central mountainous area; only 2 , or $33 \%$, have been recorded in the Mediterranean area (Tab. 1). This kind of distribution is a consequence of the biological characteristics of the species within the family, the hydrological features of Croatia in the separate regions (Pannonian and Peri-Pannonian, upland and Mediterranean), and of certain geological processes that occurred in the past and had a considerable influence on the distribution and speciation of Trichoptera in south-eastern Europe. Only two species, Agrypnia varia and Phryganea grandis, are distributed in all the three geographical regions of Croatia (Tab. 1) whereas Hagenella clathrata and Oligostomis reticulata have been recorded in just one area: the first one in the Pannonian and Peri-Pannonian, and the second in the upland (central mountainous) region of Croatia (Marinković-Gospodnetić, 1979; Previšić et al., 2013) (Tab. 1). Trichoptera research carried out in Croatia in the last years (Graf et al., 2008; Kučinić et al., 2017b; Previšić et al., 2013; Waringer et al., 2009) resulted in 5 species from the family Phryganeidae (Tab. 1) but O. reticulata recorded in the area of the Gacka River (Marinković-Gospodnetić, 1979) is unknown elsewhere.

It is specific for the family of Phryganeidae in Croatia that $50 \%$ of the species are rare or very rare, and therefore endangered. Conservation measures will be necessary for those species (O. reticulata, $H$. clathrata and T. minor).

Tab. 1. Biodiversity and distribution of family Phryganeidae in Croatia.

\begin{tabular}{|l|c|c|c|}
\hline \multicolumn{1}{|c|}{ Species } & Pannonian and Peri-Pannonian part & Central-mountain part & Mediterranean part \\
\hline Agrypnia varia & $\bullet$ & $\bullet$ & $\bullet$ \\
\hline Haganella clathrata & $\bullet$ & - & - \\
\hline Phryganea bipunctata & $\bullet$ & $\bullet$ & - \\
\hline Phryganea grandis & $\bullet$ & $\bullet$ & - \\
\hline Oligostomis reticulata & - & $\bullet$ & - \\
\hline Trichostegia minor & $\bullet$ & 5 & 2 \\
\hline TOTAL & 5 & & $\bullet$ \\
\hline
\end{tabular}


For the sake of finding and DNA barcoding O. reticulata we collected additional Trichoptera in the Gacka River area in 2016 and 2017, and at the spring of the Kostelka River in 2019. For the same reasons, we carried out similar field sampling in the Banovina and in part of the Kordun region for detecting $H$. clathrata in the 2016-2018 period (KučınIć et al., 2020). During this research we found neither one of these two species (Kučinić et al., 2020) but without success; the research will be carried on during 2020 in the hope of finding and DNA barcoding these two species.

Tab. 2. GenBank BOLD COI data for DNA barcoding specimens from family Phryganeidae collected in Croatia.

\begin{tabular}{|l|l|l|l|l|}
\hline \multicolumn{1}{|c|}{ Species } & Specimen ID & \multicolumn{1}{|c|}{ Locality } & BOLD Sequence ID & \multicolumn{1}{c|}{$\begin{array}{c}\text { Species identification } \\
\mathbf{( \% )}\end{array}$} \\
\hline Agrypnia varia & TAVAR_1 & $\begin{array}{l}\text { River Mura (lower part) } \\
\text { Goričan }\end{array}$ & CROAA013-18 & A. varia $100 \%$ \\
\hline Agrypnia varia & TAVAR_2 & spring Rude & CROTR078-19 & A. varia $99.84 \%$ \\
\hline Agrypnia varia & TAVAR_3 & $\begin{array}{l}\text { Kozjak Lake, NP Plitvice } \\
\text { Lakes }\end{array}$ & CROTR240-19 & A. varia $99.81 \%$ \\
\hline Phryganea bipunctata & TPBIN_1 & River Drava, Gornji Hrašćan & CROAA026-18 & P. bipunctata $100 \%$ \\
\hline Phryganea grandis & TPGRA_1 & River Danube, Zlatna Greda & CROAA134-18 & P. grandis $99.05 \%$ \\
\hline Trichostegia minor & TTMIN_1 & $\begin{array}{l}\text { spring of the Gacka River, } \\
\text { Majerovo vrilo }\end{array}$ & CROAA133-18 & T. minor $98.93 \%$ \\
\hline
\end{tabular}

DNA barcoding and phylogenetic features of Trichostegia minor and other species from the Phryganeidae family

With respect to molecular genetics, four Croatian Phryganeidae species were DNA barcoded until now (Tab. 2). In total, 6 specimens were analysed and the data obtained were entered in the BOLD system. The most interesting species that we recorded was Trichostegia minor, two specimens of which were collected in the area of the Gacka River (Fig. 3A-B). This species was found at only one site in northern Croatia in the first half of the $20^{\text {th }}$ century (MALICKY, 2009) and at one site at the beginning of the $21^{\text {st }}$ century in the Cetina River (GRAF et al., 2008). In the last 20 years (for example Kučinić et al., 2008, 2017b; Cerjanec, 2012; Previšić et al., 2009, 2013, 2014) the species was found only at one site, on the Cetina River (GrAf et al., 2008) (Fig. 4).

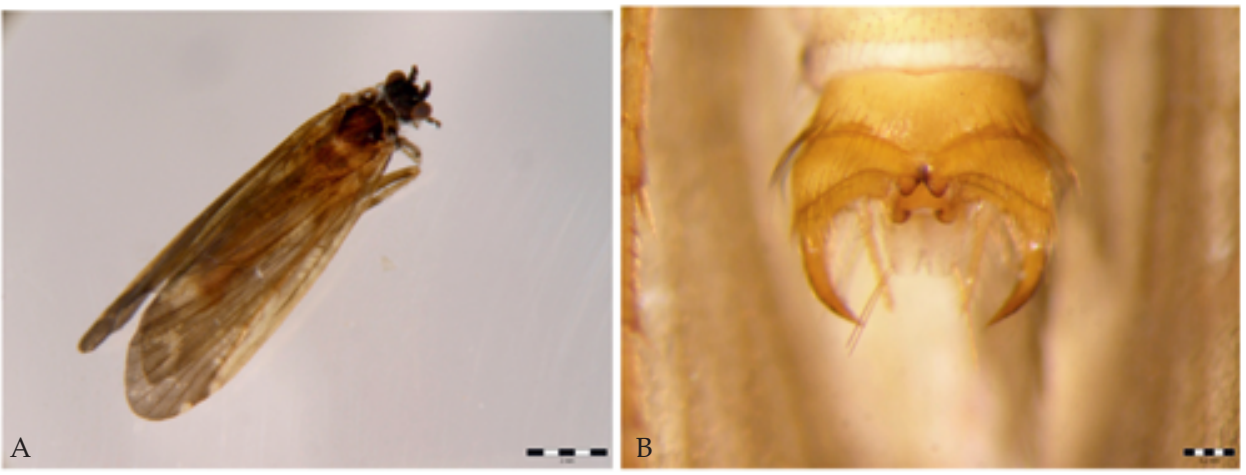

Fig. 3. Trichostegia minor Curtis, 1834, collected at the Majerovo vrilo (spring) of the Gacka River; A adult, B - male genitalia. 


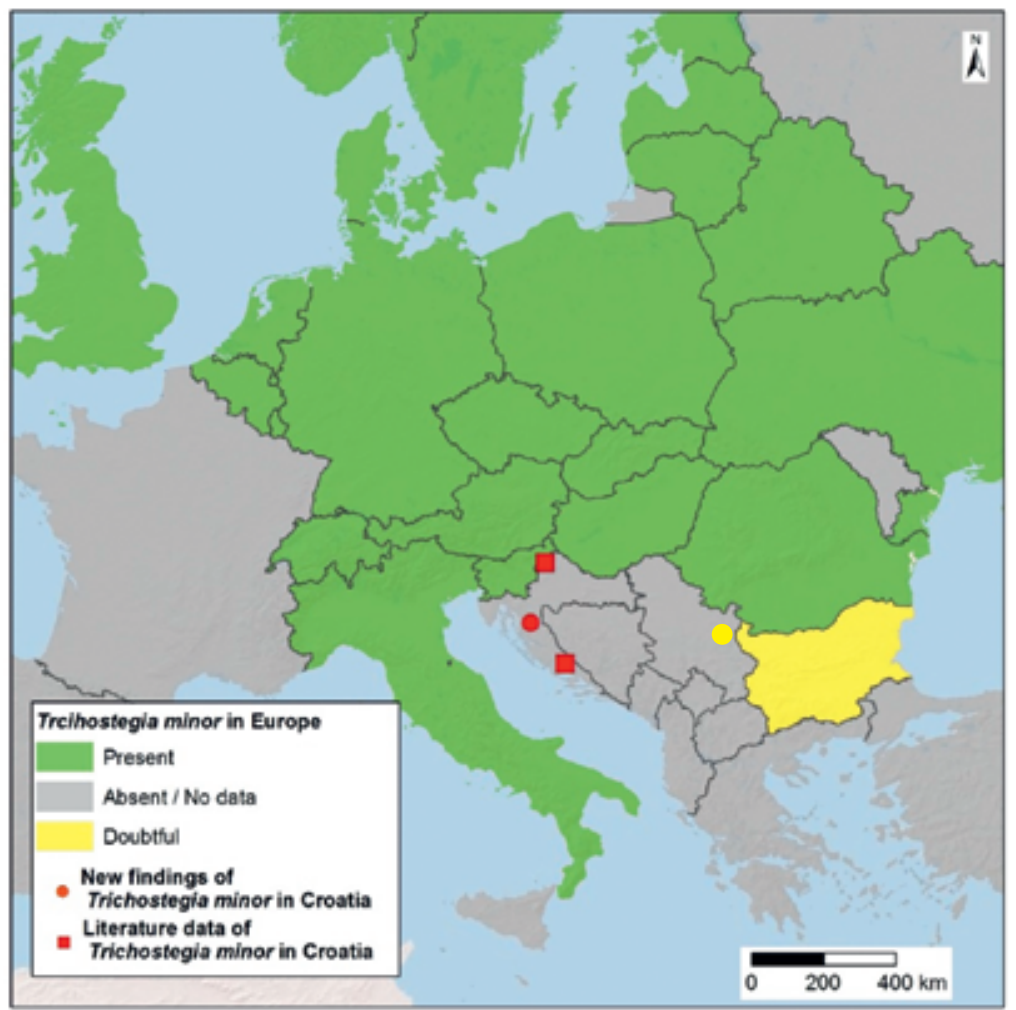

Fig. 4. Distributon of Trichostegia minor Curtis, 1834 according to the Fauna Europaea, with literature data from Graf et al., 2008 and MaLicky, 2009 (squares) and new data for the area of Croatia (red circle); yellow circle denotes finding from Serbia (SAvić et al., 2013).

The phylogenetic analysis of the Phryganeidae family conducted in the present study encompassed the species and genera recorded in Croatia, which were compared with the same species and genera from some other parts of Europe and from Asia (Fig. 5). The phylogenetic tree shows that T. minor from Croatia (TTMIN_1) is grouped with other T. minor specimens (Fig. 5). Specimen TTMIN_1 is highly similar to T. minor from Austria, collected from region Schutt, near Arnoldstein, river Gail, Tümpel bei Wehranlage, BOLD ID: KJTRI226-13. It is interesting how two specimens, TTMIN_1 from Croatia and KJTRI226-13 from Austria are separated from other T. minor specimens. We observed that two or more separate lineages occur in other species used in this study (Phryganea bipunctata, Oligostomis reticulata, Hagenella clathrata, Agrypnia varia) (Fig. 5).

The minimum interspecific difference between T. minor and other Phryganeidae is $0.1395(14 \%)$, and with the outgroup species (Lepidostoma hirtum) is 0.1572 (16\%) (Tab. 3), which is distinctly higher than the minimum difference between caddisfly species noted in literature (8.05\% in Smicridea species: PAuls et al., 2010; 8.2\% in Anisogamus species: Graf et al., 2015). As already noticed, the most similar specimen to T.minor (TTMIN_1) is KJTRI226-13 with only 0.0059 (0.6\%) difference in the COI region of mtDNA, when compared to other T. minor specimens that on 
average differ in $0.0227(2 \%)$. The low value of the intraspecific differences (among all Phryganeidae) is $0.002(0.2 \%)$ what is in line with the observed variability within Drusus species (Kučinić et al., 2015), Anisogamus species (Graf et al., 2015) and Micropterna species (Kučınić et al., 2017a). Intraspecific differences are up to $0.016(1.6 \%)$ between $P$. grandis and P. bipunctata, $0.0275(2.8 \%)$ between T. minor and $O$. reticulata, 0.0354 (3.5\%) within $A$. varia and $0.045(4.5 \%)$ within $H$. clathrata. In Tab 3. we can notice that high intraspecific differences between species $P$. grandis specimens from Europe and subspecies $P$. grandis rotundata from Mongolia is $0.016(1.6 \%)$. If we compare to maximum intraspecific differences observed in the mtCOI barcode region reported in other studies (Hydropsychidae maximum intraspecific distance $=0.9 \%$ in GERECI et al., 2011, 3.19\% between Xanthochorema species in Johanson et al., 2007, 3.9\% between Ceratopsyche in ZHou et al., 2007, 5.3\% between Cheumatopsyche campyla Ross, 1938 in ZHOU, 2009) those observed distances are relatively high. More confusing is that the minimum interspecific difference is close to the maximum intraspecific distance (1.9\% in GERECI et al., 2011, 3.5\% in Zhou, 2009, 8\% in Johanson et al., 2007, 9.6\% in Zhou et al., 2007).

The ABGD analysis revealed 11 genetic groups (Fig. 5). Interspecific distances of T. minor with other specimens did not overlap with intraspecific divergences, as shown by the ABGD analysis (Fig. 6). We observed that ABGD groups do not completely reflect the pattern of branching in the phylogenetic tree. Although $P$. grandis rotundata Ulmer, 1905 specimens form well supported subclade within $P$. grandis clade, separated from $P$. grandis grandis, specimens belonging to both subspecies are encompassed within single ABGD group (Group 1). The same is true for two distinct lineages within H. clathrata (Group 6). On the other hand, the specimens belonging to the same species are separated in distinct ABGD groups in the case of ( $P$. bipunctata in Group 2 and Group 3, O. reticulata in Group 4 and Group 5, A. varia in Group 9 and Group 10) (Fig. 5). T. minor from Croatia (TTMIN_1) and Austria (KJTRI226-13) formed separate group from the rest of $T$. minor specimens (Group 8) (Fig. 5).

Tab. 3. Uncorrected pairwise divergences ( $p$ distances) among mtCOI haplotypes (DNA barcode region) of the analysed Phryganeidae.

\begin{tabular}{|l|l|l|l|l|l|l|l|}
\hline & $\begin{array}{c}\text { T. minor } \\
\text { (TTMIN_1 \& } \\
\text { KJTRI226-13 }\end{array}$ & T. minor & $\begin{array}{c}\text { Agrypnia } \\
\text { varia }\end{array}$ & $\begin{array}{c}\text { Hagenella } \\
\text { clathrata }\end{array}$ & $\begin{array}{c}\text { Oligostomis } \\
\text { reticulata }\end{array}$ & $\begin{array}{c}\text { Phryganea } \\
\text { bipunctata }\end{array}$ & $\begin{array}{c}\text { Phryganea } \\
\text { grandis }\end{array}$ \\
\hline $\begin{array}{l}\text { T. minor } \\
\text { (TTMIN_1 \& } \\
\text { KJTRI226-13 }\end{array}$ & 0.5 & & & & & & \\
\hline T. minor & $2-2.8$ & $0-0.1$ & & & & & \\
\hline $\begin{array}{l}\text { Agrypnia } \\
\text { varia }\end{array}$ & $16.11-17$ & $15.7-17.0$ & $0.20-3.5$ & & & & \\
\hline $\begin{array}{l}\text { Hagenella } \\
\text { lathrata }\end{array}$ & $15.7-16.5$ & $15.3-16.5$ & $14.7-16.5$ & $0.4-4.5$ & & & \\
\hline $\begin{array}{l}\text { Oligostomis } \\
\text { reticulata }\end{array}$ & $14.3-15.1$ & $13.9-15.3$ & $14.1-15.7$ & $13.4-14.5$ & $0.2-2.8$ & & \\
\hline $\begin{array}{l}\text { Phryganea } \\
\text { bipunctata }\end{array}$ & $16.3-17.2$ & $16.3-17.4$ & $16.3-17.1$ & $14.3-15.3$ & $14.3-15.3$ & $0.1-1.8$ & \\
\hline $\begin{array}{l}\text { Phryganea } \\
\text { grandis }\end{array}$ & $14.5-15.2$ & $14.3-15.9$ & $15.5-16.7$ & $13.9-15.7$ & $12.6-13.8$ & $8.8-10.2$ & $0.2-1.6$ \\
\hline $\begin{array}{l}\text { Lepidostoma } \\
\text { hirtum }\end{array}$ & $15.9-16.1$ & $15.7-16.1$ & $15.7-17.1$ & $16.7-18.1$ & $17.1-17.5$ & $18.3-19.1$ & $15.7-16.1$ \\
\hline
\end{tabular}




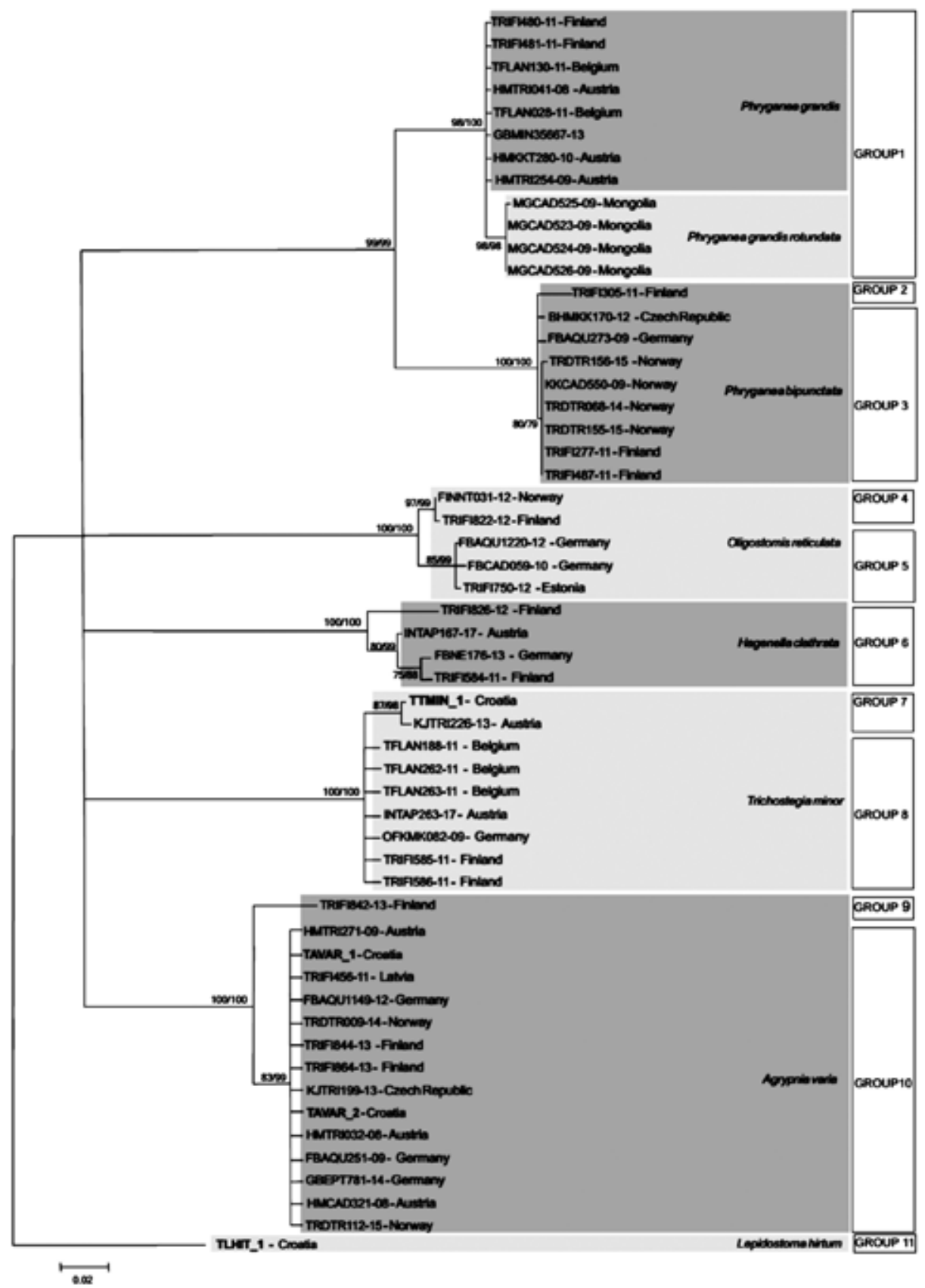

Fig. 5. Maximum likelihood (ML) phylogram based on a $658 \mathrm{bp}$ long fragment of the DNA barcode region showing the relationships in Phryganeidae with species Lepidostoma hirtum as outgroup. Numbers above the branches represent bootstrap support (BS) for Neighbor-Joining (NJ) and ML analysis (NJ/ML). BS values less than 70 are not shown. The groups delineated by the Automatic Barcode Gap Discovery (ABGD) approach are shown on the right side of the tree. 


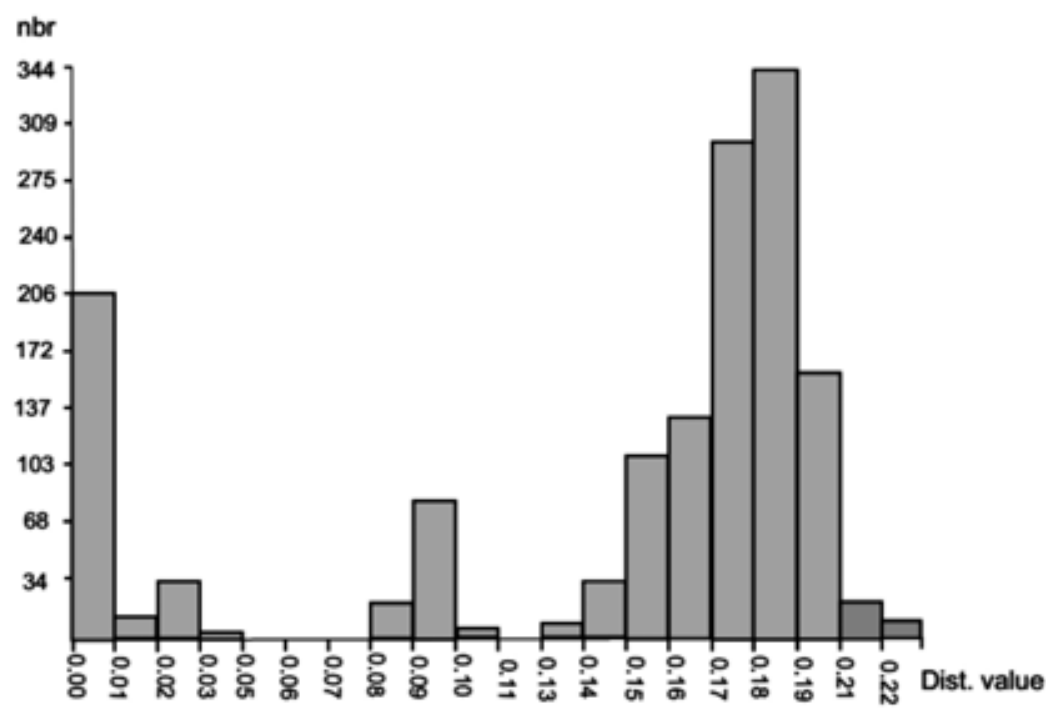

Fig. 6. Histogram depicting the frequency distribution of K2P distances for species of the Phryganeidae family used in this study, calculated by ABGD. The horizontal axis shows the pairwise K2P-distance, and the vertical axis shows the number of pairwise sequence comparisons.

\section{DNA barcoding and faunistics of caddisflies at the River Gacka}

In this recent study from the area of the Gacka River nine Trichoptera species were DNA barcoded (Tab. 4). In total 11 specimens were analysed and the data obtained were entered in the BOLD system (Tab. 4).

The studies of adult caddisflies in the area of the River Gacka was conducted by Mara Marinković-Gospodnetić, a professor from Sarajevo, who recorded 4 species at the Sinac and Majerov vrilo springs (Marinković-Gospodnetić, 1979), including the species Drusus croaticus Marinković-Gospodnetić, 1971. It was originally described by Professor Marinković-Gospodnetić from the area of the Plitvice lakes (Marinković-Gospodnetić, 1971); afer that the species was found in other areas of upland Croatia, including the springs of the Gacka River (MARinković-Gospodnetić, 1971).

Today, 17 caddisfly species from 15 genera and 11 families are known from the area of the Gacka River: family Rhyacophilidae - Rhyacophila fasciata Hagen, 1859 (the River Gacka, Otočac); family Glossostomatidae - Agapetus ochripes Curtis, 1834 (the River Gacka, Otočac); family Hydroptilidae - Hydroptila martini Marshall, 1977 (the River Gacka, Otočac), Hydroptila tineoides Dalman, 1819 (the River Gacka, Otočac); family Polycentropodidae - Polycentropus flavomaculatus (Pictet, 1834) (Tonkovića vrilo, spring); family Psychomyiidae - Psychomia klapaleki Malicky, 1995 (the River Gacka, Otočac); family Phryganeidae - Oligostomis reticulata, Trichostegia minor; family Hydropsychidae - Hydropsyche bulbifera McLachlan, 1878 (the River Gacka, Otočac); family Lepidostomatidae - Lepidostoma hirtum (the River Gacka, Otočac); family Limnephilidae - Drusus croaticus (Tonkovića 
vrilo, spring), Limnephilus flavicornis (Fabricius, 1787) (Majerovo vrilo, spring), Limnephilus rhombicus (Linnaeus, 1758) (the River Gacka, Oročac), Micropterna testacea (Gmelin, 1789) (Majerovo vrilo, spring), Potamophylax cf. latipennis (Curtis, 1834) (Tonkovića vrilo, spring; the River Gacka, Otočac); family Odontoceridae - Odontocerum albicorne (Scopoli, 1763) (the River Gacka, Otočac); family Leptoceridae - Oecetis notata Rambur, 1842 (Majerovo vrilo, spring). Apart from Trichostegia minor the following species from the area of the Gacka River area are also interesting from a faunistic viewpoint: Hydroptila martini, H. tineoides, Hydropsyche bulbifera and Oecetis notata. H. martini and H. bulbifera were recorded for the first time in the upland part of Croatia, and the other two have been found very seldom in Croatia, at two to three sites only (CERJANEC, 2012).

On the River Kostelka 8 species were recorded (M-G 1979) of which 5 species were not found in the River Gacka: Plectrconemia conspersa (Curtis, 1834) (family Polycentropodidae), Oligostomis reticulata (family Phryganeidae), Chaetopteryx bosniaca Marinković-Gospodnetić, 1959 (family Limnephilidae), Stenophylax vibex (Curtis, 1834) (family Limnephilidae) and Beraea pullata (Curtis, 1834).

Tab. 4. GenBank and BOLD COI barcode data for DNA barcoding specimes collected from the area of the Gacka River.

\begin{tabular}{|l|l|l|l|}
\hline Species & Specimen ID & BOLD Sequence ID & Location \\
\hline Trichostegia minor & TTMIN_1 & CROAA133-18 & river Gacka, spring Majerovo vrilo \\
\hline Hydroptila martini & THMAR_1 & CROAA094-18 & river Gacka, Otočac \\
\hline Psychomyia klapaleki & TPKLA_2 & CROAA112-18 & river Gacka, Otočac \\
\hline Drusus croaticus & TDCRO_3 & CROTR019-19 & river Gacka, spring Majerovo vrilo \\
\hline Drusus croaticus & TDCRO_4 & CROTR043-19 & river Gacka, spring Majerovo vrilo \\
\hline Limnephilus flavomaculatus & TLFLA_1 & CROTR073-19 & river Gacka, spring Majerovo vrilo \\
\hline Limnephilus rhombicus & TLROM_1 & CROAA097-18 & river Gacka, Otočac \\
\hline Limnephilus rhombicus & TLRHO_5 & CROTR188-19 & river Gacka, spring Majerovo vrilo \\
\hline Micropterna testacea & TMTES_3 & CROTR028-19 & river Gacka, spring Majerovo vrilo \\
\hline Oecetis notata & TONOT_2 & CROTR072-19 & river Gacka, spring Majerovo vrilo \\
\hline Hydropsyche bulbifera & THBUL_3 & CROTR039-19 & river Gacka, Otočac \\
\hline
\end{tabular}

\section{CONCLUSION}

Six species from the family Phryganeidae have been recorded in the Croatian fauna (Tab. 1). In this recent research, four of them were collected and DNA barcoded (Tab. 2). In total, 6 specimens were analysed and the data obtained were entered in the BOLD system.

Phylogenetic analysis of the DNA barcoded specimens from Croatia showed that our species group fits well with European specimens of the same species put into the BOLD system, such as Agrypnia varia (Fig. 3).

T. minor collected in the Gacka River area and DNA barcoded (Tabs. 2, 5) forms, together with a specimen of the same species from Austria, distinct subclade within T. minor clade which indicates small molecular specificity. Our 
phylogenetic analysis has confirmed the justifiability of the subspecies status of Phryganea grandis rotundata from Mongolia (Fig. 3).

In future Trichoptera research in Croatia, the Phryganeidae family will be included for the purpose of new records, a more detailed distribution of already recorded species and the re-discovery and barcoding of Hagenella clathrata and Oligostomis reticulata. It will be necessary establish conservation measurements necessary for their protection and the protection of their habitats as they seem to be very rare in the Croatian fauna, which refers to T. minor as well.

\section{ACKNOWLEDGEMENT}

We are very grateful to two anonymous referees for their useful suggestions and also to Graham McMaster for his assistance with English; we thank the Faculty of Forestry for the macrophotography.. This study was supported by the "EU Natura 2000 Integration Project (NIP)" funded by the Croatian Ministry of Environmental and Nature Protection (2012-2016), and the scientific project „DNA barcoding of Croatian faunal biodiversity" (IP-06-2016-9988)“ (2017-2021) funded by the Croatian Science Fundation.

Received November 28, 2019

\section{REFERENCES}

Bertić, I., Lampek Pavčnik, I. \& Radovinović, R., 2001: Republika Hrvatska-Prirodna obilježja, stanovništvo i geografske regije (In: Satelitski Atlas Hrvatske). Naknada Ljevak \& GisData, pp 336.

Bilandžija, H., Morton, B., Podnar M. \& Ćetкović, H., 2013: Evolutionary history of relict Congeria (Bivalvia: Dreissenidae): unearthing the subterranean biodiversity of the Dinaric Karst. Frontiers in Zoology 10, 5. http://www.frontiersinzoology.com/content/10/1/5

Brehm, G., Murillo-Ramos L., Sihvonen, P., Hausmann, A., Schmidt, C.B., 5, Öunap, E., Moser, A., Mörtter, R., Bolt, D., Bodner, F., Lindt, A., Parra L.E. \& Wahlberg, N., 2019: New World geometrid moths (Lepidoptera: Geometridae): Molecular phylogeny, biogeography, taxonomic updates and description of 11 new tribes. Arthropod Systematic and Phylogeny 77 (3), 457-486. DOI: 10.26049/ASP77-3-2019-5

Bogdanović, S., Brullo, S., ReŠetnik, I., Šatović, Z. \& Liber, Z., 2014: Campanula teutana, a new isophyllous Campanula (Campanulaceae) from the Adriatic region. Phytotaxa 162 (1), 1-17. doi:10.11646/phytotaxa.162.1.1.

Bogdanović, S., Rešetnik, I., Jeričević, M., Jeričević, N. \& Brullo, S., 2019: Molecular and morphological survey on Campanula cremnophila (Campanulaceae), a new isophyllous species from Croatia. Plant Systematics and Evolution 305 (8), 687-703.

CERJAnEc, D., 2012: Ekološke i biogeografske značajke faune tulara (Insecta: Trichoptera) u različitim tipovima staništa sliva rijeke Dobre. Doktorska disertacija (PhD Thesis), Prirodoslovnomatematički fakultet, Sveučilište u Zagrebu (Faculty of Science, University of Zagreb), 172 pp (in Croatian).

Cianficconi, F., 2002: The third list of Italian Trichoptera (1990-2000). Proceedings of the 10th International Symposium on Trichoptera (Ed. Mey, W.) Nova Supplementa Entomologica Keltern 15, 349-358.

Ćukušić, A., Ćuk, R., Previšić, A., Podnar, M., Delić, A. \& Kučinić, M., 2017: A barcoding and first records of two rare Adicella species (Trichoptera: Leptoceridae) in Croatia. Biologia 72: 796-806. https://doi.org/10.1515/biolog-2017-0087

DAyrat, B., 2005: Towards integrative taxonomy. Biological Journal Linn. Soc. 85, 407-415. 
Da Silva, G.L., Da Cunha, U.S., Rocha, M.S., Panou, E.N \& Ferla, N.J., 2014: Tydeid and triophtydeid mites (Acari: Tydeoidea) associated with grapevine (Vitaceae: Vitis spp.) in Brazil, with the descriptions of species of Prelorryia (André, 1980) and Tydeus Koch, 1835. Zootaxa 3814 (4), 495-511.

FANG, Y. \& XING, J., 2019: Description of a new leafhopper species of the genus Longicornus (Hemiptera, Cicadellidae, Deltocephalinae) from China, with a revised key to species. ZooKeys 888, 67-73.

Fauna Europaea, https//fauna-eu..org (accessed November 2019).

Geraci, C. J., Al-Saffar, M. A., \& Zhou, X., 2011: DNA barcoding facilitates description of unknown faunas: a case study on Trichoptera in the headwaters of the Tigris River, Iraq. J. N. Am. Benthol. Soc. 30(1), 163-173.

Graf, W., Kučinić, M., Previšić, A, Vučković, I. \& Waringer, J., 2008: The Larva, ecology and distribution of Tinodes braueri McLachlan, 1878 (Trichoptera: Psychomyiidae). Aquatic insects 30 (4), 295-299.

Graf, W., Vitecek, S., Previšić, A. \& Malicky, H., 2015: New species of Limnephilidae (Insecta: Trichoptera) from Europe: Alps and Pyrenees as harbours of unknown biodiversity. Zootaxa 3911 (3), 381-395. http://dx.doi.org/10.11646/zootaxa.3911.3.5

HaLl, T.A., 1999: BioEdit. A user-friendly biological sequence alignment editor and analysis program for Windows 95/98/NT. Nucl. Acids Symp. Ser. 41, 95-98.

Hebert, P.D.N., Cywinska, A., Ball, S.L. \& DeWAard, J.R., 2003a: Biological identifications through DNA barcodes. Proc. R. Soc. Lond. B. Biol. Sci. 270, 313-322.

Hebert, P.D.N., Ratnasingham, S. \& DeWaArd, J.R., 2003b: Barcoding animal life: Cytochrome c oxidase subunit 1 divergences among closely related species. Proc R Soc Lond B Biol Sci 270, S596-S599.

Hjalmarsson, A., Graf, W., Vitecek, S., Jähnig, C.S., Cai, Q., Sharma, S., Tong, X., Li, F., Shah, D.N., ShaH, R.D.C. \& Pauls, S.U., 2019: Molecular phylogeny of Himalopsyche (Trichoptera, Rhyacophilidae). Systematic Entomology doi: 10.1111/syen.12367

Holzenthal, R.W., Blahnik, R.J., Prather, A.L. \& KJer, K.M., 2007: Order Trichoptera Kirby, 1813 (Insecta), Caddisflies. Zootaxa 1668, 639-698.

Ibrahimi, H., Vitecek, S., Previšić, A., Kučinić, M., Waringer, J., Graf, W., Balint, M., Keresztes, L. \& PAULS, S.U., 2016: Drusus sharrensis sp. n. (Trichoptera, Limnephilidae), a new species from sharr national park in Kosovo, with molecular and ecological. Zookeys 559, 107-124.

ICZN (International Code of Zoological Nomenclature), 2000: International Commission on Zoological Nomenclature, Fourth Edition, published by The International Trust for Zoological Nomenclature 1999 c/o The Natural History Museum, London, pp. 105.

Johanson, K. A., 2007: Association and description of males, females and larvae of two New Caledonian Xanthochorema species (Trichoptera: Hydrobiosidae) based on mitochondrial $16 \mathrm{~S}$ and COI sequences. Entomol. Sci., 10(2), 179-199.

Krušnik , C. \& Urbanič, G., 2002: Preliminary List of Slovenian Trichoptera. Proceedings of the 10th International Symposium on Trichoptera (Ed. Mey, W.). Nova Supplementa Entomologica 15, 359-364.

Kučınıć, M., 2002: Raznolikost i rasprostranjenost tulara u staništima Plitvičkih jezera (Insecta, Trichoptera). Doktorska disertacije (PhD Thesis), Priridoslovno- matematički fakultete, Sveučilište u Zagrebu (Faculty of Science, University of Zagreb), 139 pp, (in Croatian).

KučINIĆ, M., 2019: Biodiversity of caddisflies (Insecta, Trichoptera) in Croatia with a notice with particular refernce to DNA barcoding. Proceeding oft he 7th Aquatic Biodiversity International Conference, Sibiu, 22.

Kučinić, M., Previšić, A., Gottstein, A., Hrašovec, B., Stanić-Koštroman S., Pernek, M. \& Delić, A., 2008: Description of the larvae of Drusus radovanovici septentrionis Marinković-Gospodnetić, 1976 and Drusus croaticus Marinković-Gospodnetić, 1971 (Trichoptera: Limnephilidae) from Bosnia and Herzegovina and Croatia. Zootaxa 1783, 1-17.

Kučinić, M., Szivák, I., Pauls, S.U., BÁlint, M., Delić, A. \& VučKović' I., 2013: Chaetopteryx bucari sp. n. a new species from the Chaetopteryx rugulosa group from Croatia (Insecta, Trichoptera) with some molecular, taxonomical and ecological notes on the group. Zookeys 320, 1-28. 
Kučinić, M., Previšić, A., Graf, W., Mihoci, I., Šoufek, M., Stanić-Koštroman, S., Lelo, S., ViteceK, S. \& Waringer, J., 2015: Larval description of Drusus bosnicus Klapálek 1899 (Trichoptera: Limnephilidae), with distributional, molecular and ecological features. Zootaxa 3957(1), 85-97.

Kučinić, M., Ćukušić, A., Žalac, S., Podnar, M., Kambarovich Akhmetov, K., Акimbekova, N., Moldazhanovna Zhumadina, S. \& VučKović, I., 2017a: First DNA barcoding and new records of the Mediterranean caddisfly species Micropterna wageneri Mal. (Trichoptera, Limnephilidae) in Croatia with note on DNA barcoding and diversity of genus Micropterna in Croatia. Natura Croatica, 26(1), 81-98.

Kučinić, M., Previšić, A., Vajdić, M., Tunjić, M., Mihoci, I., Žalac S., Sviben, S., Vučković, I., Trupković, M. \& Habdija I., 2017b: First systematic investigation of adults and second checklist of caddisflies of the Plitvice Lakes National Park with notes on research history, biodiversity, distribution and ecology. Nat. Croat. 26, 225-260.

Kučinić, M., Delić, A., Bučar, M., Plavac, H., Ćukušić, A., Ćuk, R., Cerjanec, D., Vučković, I. \& Gjurašın, B., 2020: Prvi nalaz tulara Agraylea sexamaculata Curtis, 1834 (Insecta, Trichoptera) na području kontinentalnog dijela Hrvatske s nadopunjenom check-listom Trichoptera Banovine i kratkim osvrtom na DNA barkodiranje. Zbornik „Zrinska gora, regionalni park“ (ed. BučAR M.): (in press).

Kumanski, K.P., 1988: Trichoptera, Integripalpia. Fauna Bulgarica 19, 1-354.

Kumar, S., Stecher, G., \& Tamura, K., 2016: MEGA7: Molecular Evolutionary Genetics Analysis version 7.0 for bigger datasets. Mol. Biol. Evol. 33 (7), 1870-1874.

Linnaeus, C., 1758: Systema naturae per regna tria naturae :secundum classes, ordines, genera, species, cum characteribus, differentiis, synonymis, locis (in Latin). Stockholm: Laurentius Salviu,

Malicky, H., 2004: Atlas of European Trichoptera. Springer, Dordrecht, 384 pp.

Malicky, H., 2009: Die Köcherfliegen (Insecta, Trichoptera) der Sammlung Franjo Košćec im Museum Varaždin, Kroatien. Nat. Croat. 18 (1), 129-134.

Malicky, H., 2017: Neue Köcherfliegen (Trichoptera) aus Nepal, mit Bemerkungen zu bekannten Arten sowie Meldungen von Neufunden für das Land. Linzer biologische Beiträge 49(2), 1453 1488.

Marinković-Gospodnetić, M., 1971: The species of the genus Drusus in Yugoslavia. Godišnjak Biološkog Instituta Univerziteta Sarajevo (Annual of the Institute of Biology - University of Sarajevo) 24, 105-109.

Marinković-Gospodnetić, M., 1979: Trichoptera (Insecta) velikih karstnih izvora u Dinaridima. In: RAuš, Đ. (Ed.), Drugi kongres Ekologa Jugoslavije (Second Congress of Ecologists of Yugoslavia). Savez društava ekologa Jugoslavije. Zagreb, pp. 1837-1849.

Morse, J.C. (ed.), 2019: Trichoptera World Checklist. http://entweb.clemson.edu/database/trichopt/ index.htm [acess 4 December 2019.]

Nógardi, S \& Uherkovichc, A., 2002: Magyarország Tegzesei (Trichoptera) (The caddisfly of Hungary Trichoptera). Studia Pannonica (A), Series Historico-Naturalis 11, 1-386.

Pauls, S.U., Lumbsch, H.T. \& HaAse P., 2006: Phylogeography of the montane caddisfly Drusus discolor: Evidence for multiple refugia and periglacial survival. Molecular Ecol. 15, 2153-2169. DOI: 10.1111/j.1365-294X.2006.02916.x

Pauls, S.U., Theissinger, K., Ujvarosi, L., Balint M. \& Haase, P., 2009: Patterns of population structure in two closely related, partially sympatric caddisflies in Eastern Europe: historic introgression, limited dispersal, and cryptic diversity. J. North Am. Benthol. Soc. 28 (3), 517-536. DOI: $10.1899 / 08-100.1$

Pauls, S.U., Blahnik, R.J., Zhou, X., Wardwell, C.T. \& Holzenthal, R.W., 2010: DNA barcode data confirm new species and reveal cryptic diversity in Chilean Smicridea (Smicridea) (Trichoptera: Hydropsychidae). J. N. Am. Benthol. Soc. 29 (3), 1058-1074. doi: 10.1899/09-108.1

Pfeiler, E., 2018: DNA Barcoding and Taxonomic Challenges in Describing New Putative Species: Examples from Sootywing and Cloudywing Butterflies (Lepidoptera: Hesperiidae). Diversity 10, 111, doi:10.3390/d10040111 
Previšić, A., Walton, C., Kučinić, M., Mitrikeski, P.T. \& Kerovec, M., 2009: Pleistocene Divergenceof Dinaric Drusus endemics (Trichoptera, Limnephilidae) in multiple microrefugia within the Balkan Peninsula. Molecular Ecol. 18, 634-647. doi: 10.1111/j.1365-294X.2008.04046.x

Previšić, A., Brigić, A, Sedlar, Z. \& Šoštarić, R., 2013: First data on caddisfl y (Insecta, Trichoptera) fauna of peatlands in croatia. Nat. Croat. 22, 235-242, 2013, Zagreb.

Previšić, A., Schnitzler, J., Kučinić, M., Graf, W., Ibrahimi, H., Kerovec M. \& Pauls, S.U., 2014: Micro-Scale Vicariance and Diversification of Western Balkan Caddisflies Linked to Karstification. Freshwater Science 33 (1) 250-262.

Puillandre, N., Lambert, A., Brouillet, S. \& Achaz, G., 2012: ABGD, Automatic Barcode Gap Discovery for primary species delimitation. Mol. Ecol. 21 (8), 1864-1877.

Radovanović, M., 1935: Trichoptere Jugoslavije. Glasnik zemaljskog muzeja u Sarajevu 47, 73-84.

Ratnasingham, S. \& Hebert, P.D.N., 2007: BOLD - The Barcode of Life Data System (www. barcodinglife.org). Mol. Ecol. Notes 7, 355-364. doi:10.1111/j.1471-198286.2006.01678.x

Savić, A., RanĐelović, V., ĐorĐević, M., Karadžić, B., Đokić, M. \& Krpo-ĆetKović, J., 2013: The influence of environmental factors on the structure of caddisfly (Trichoptera) assemblage in the Nišava River (Central Balkan Peninsula). Knowledge and Management of Aquatic Ecosystem 409, 03, 03 DOI: 10.1051/kmae/2013051

Sumannarat, N., Malicky, H., Morse, J.C. \& Laudee, P., 2019: Four new species of Rhyacophila Pictet, 1834 (Trichoptera: Rhyacophilidae) from Southeast Asia. Zootaxa 4657 (2), 369-376.

Szivak, I., Mikes, T., Szalontai, B., Kučinić, M., VučKović, I., Vadkerti, E., Kisfali, P., Pauls, S.U. \& BÁLINT, M., 2017: Ecological divergence of Chaetopteryx rugulosa species complex (Insecta, Trichoptera) linked to climatic niche diversification. Hydrobiologia 794, 31-47.

Vitecek, S., Graf, W., Previšić, A., Kučinić, M., Oláh, J., Bálint, M., Keresztes, L., Pauls, S.U. \& WARINGER, J., 2015a: A hairy case: The evolution of filtering carnivorous Drusinae (Limnephilidae, Trichoptera). Mol. Phylogenetic Evol. 93, 249-260.

Vitecek, S., Kučinić, M., Oláh, J., Previšić, A., Bálint, M., Keresztes, L., Waringer, J., Pauls, S.U. \& Graf, W., 2015b: Description of two new filtering carnivore Drusus species (Limnephilidae, Drusinae) from the Western Balkans. Zookeys 513, 79-104.

Vitecek, S., Previšić, A., Kučinić, M., Bálint, M., Keresztes, L., Waringer, J., Paulus, S.U., Malicky, H. \& GRAF, W., 2015c: Description of a new species of Wormaldia from Sardinia and a new Drusus species from the western Balkans (Trichoptera, Philopotamidae, Limnephilidae). Zookeys 496, 85-103.

Vitecek, S., Kučinić, M., Previšić, A., Živić, I., Stojanović, K., Keresztes, L., Bálint, M., Hoppeler, F., Waringer, J., Graf, W. \& Pauls, U. S., 2017: Integrative taxonomy by molecular species delimitation : multi-locus data corroborate a new species of Balkan Drusinae microendemics. BMC Evolutionary Biology 17, 129-1-129-18.

Villesen, P. 2007: FaBox: an online toolbox for fasta sequences, Mol. Ecol. Notes 7 (6), 965-968. doi:10.1111/j.1471-8286.2007.01821.x

Waringer, J., Graf, W., Kučinić, M., Previšić, A. \& VučKović, I. 2009: The Larva and life cycle of Annitella apfelbecki Klapalek, 1899, including a re-description of Melampophylax nepos McLachlan, 1880 (Trichoptera: Limnephilidae). Aquatic insects, 31 (1), 71-80.

Will, K.P., Mishler, B.D. \& Wheeler Q.D., 2005: The perils of DNA Barcoding and the need for integrative taxonomy. Syst. Biol. 54, 844-851.

Yánez-Muñoz, M.H., Reyes-Puig, C., Reyes-Puig, J.P., Velasco, J.A., Ayala-Varela, F., TorresCarvaja, O., 2018: A new cryptic species of Anolis lizard from northwestern South America (Iguanidae, Dactyloinae). ZooKeys 794, 135-163.

Zноu, X., 2009: The larvae of Chinese Hydropsychidae (Insecta: Trichoptera), Part I: Arctopsyche shimianensis, Parapsyche sp. A, and Diplectrona obscura. Zootaxa 2174, 1-17.

Zhou, X., KJer K.M. \& Morse J.C., 2007: Associating larvae and adults of Chinese Hydropsychidae caddisflies (Insecta:Trichoptera) using DNA sequences. J. N. Am. Benthol. Soc. 26, 719-742. doi:10.1899/06-089.1. 
Appendix 1. List of specimens used in this study, showing life stage, origin, BOLD Sequence ID number, specimen ID, number of unique haplotypes. Specimens which genomic DNA was extracted in this study are written in bold letters. Abbreviation used: ID = Identification number, BOLD = Barcode of Life data system, $\mathrm{A}=$ adult, $\mathrm{I}=$ imago, $\mathrm{L}=$ larvae, $\mathrm{M}=$ male, $\mathrm{F}=$ female, No. = number

\begin{tabular}{|c|c|c|c|c|c|c|}
\hline$\underset{x}{\infty}$ & 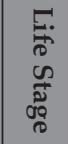 & Country & Location & $\begin{array}{l}\text { BOLD } \\
\text { Sequence ID }\end{array}$ & Specimen ID & $\begin{array}{l}\text { No. } \\
\text { haplotyp }\end{array}$ \\
\hline \multicolumn{7}{|c|}{ Trichostegia minor Curtis, 1834} \\
\hline M & A & Croatia & $\begin{array}{l}\begin{array}{l}\text { River Gacka, Spring Majerovo } \\
\text { vrilo }\end{array} \\
\end{array}$ & CROAA133-18 & TTMIN_1 & 1 \\
\hline M & I & Austria & Franstanz, Giessen & INTAP263-17 & PE310 & \multirow{2}{*}{2} \\
\hline M & I & Austria & Franstanz, Giessen & INTAP264-17 & PE311 & \\
\hline \multirow[t]{2}{*}{$\mathrm{M}$} & A & Austria & Tumpel bei Wehranlage & KJTRI226-13 & HMCAD13-36 & 3 \\
\hline & A & Germany & Karinchensee nr. Ferch & OFKMK082-09 & 09OFKMK-0082 & 4 \\
\hline \multirow[t]{3}{*}{$\mathrm{F}$} & A & Belgium & Hobokense Polder, Hoboken & TFLAN188-11 & UA-SG-TRICH-D80 & 5 \\
\hline & A & Belgium & Hobokense Polder, Hoboken & TFLAN262-11 & UA-SG-TRICH-D94 & 6 \\
\hline & A & Belgium & Bospolder, Ekeren & TFLAN263-11 & UA-SG-TRICH-D95 & 7 \\
\hline F & A & Finland & Kalkkimaeki & TRIFI585-11 & JSlk-2011F045 & \multirow{2}{*}{8} \\
\hline M & A & Norway & Tjome, Mostranda & UMNEC454-08 & RBCAD-2323 & \\
\hline $\mathrm{F}$ & A & Finland & Kalkkimaeki & TRIFI586-11 & JSlk-2011F046 & 9 \\
\hline \multicolumn{7}{|c|}{ Agrypnia varia Fabricius, 1793} \\
\hline & & Croatia & River Mura, near Goričan & & TAVAR_1 & 10 \\
\hline M & & Germany & $\begin{array}{l}\text { Donauaue } 350 \mathrm{~m} \mathrm{~W} \text { Giesenau, } \\
\text { Donau Fkm 2436,125 [rec }\end{array}$ & FBAQU1149-12 & BCZSMAQU00864 & \multirow{7}{*}{11} \\
\hline M & & Germany & $\begin{array}{l}\text { Gutendorf/Weimar, } \\
\text { Klosterholz }\end{array}$ & GBEPT776-14 & GBOL04390 & \\
\hline $\mathrm{F}$ & & Austria & $\begin{array}{l}\text { A-Salzburg,St. Georgen, } \\
\text { Waidmoos } \\
\end{array}$ & HMCAD320-08 & 07HMCAD-0320 & \\
\hline M & & Austria & Stutz & INTAP120-17 & PE143 & \\
\hline M & & Belgium & Genk & TFLAN172-11 & UA-SG-TRICH-D75 & \\
\hline \multirow[t]{2}{*}{ F } & & Belgium & Dilsen-Stokkem & TFLAN173-11 & UA-SG-TRICH-D76 & \\
\hline & $\mathrm{L}$ & Belgium & Gammelelva naturreservat & TFLAN252-11 & UA-SG-TRICH-D74 & \\
\hline M & & Germany & \begin{tabular}{|l|} 
Tegernsee, Ufer unterhalb \\
Kaltenbrunn (Gde. Gmund) \\
\end{tabular} & FBAQU251-09 & BC ZSM AQU 00251 & 12 \\
\hline M & & Germany & $\begin{array}{l}\text { Zehdennick, Eichlerstich, } \\
\text { Waldrand }\end{array}$ & GBEPT781-14 & GBOL04395 & 13 \\
\hline $\mathrm{F}$ & & Austria & $\begin{array}{l}\text { A-Salzburg,St. Georgen, } \\
\text { Waidmoos } \\
\end{array}$ & HMCAD321-08 & 07HMCAD-0321 & 14 \\
\hline M & & Austria & Mayrgraben, Lunz am See & HMTRI032-08 & 08HMCAD-032 & 15 \\
\hline M & & Austria & Zell/Ybbs & HMTRI271-09 & 08HMCAD-271 & 16 \\
\hline M & & \begin{tabular}{|l|} 
Czech \\
Republic \\
\end{tabular} & Blatenska slat` pod & KJTRI199-13 & HMCAD13-9 & 17 \\
\hline M & & Norway & Gammelelva naturreservat & TRDTR009-14 & TRD-TRI88 & \multirow{6}{*}{18} \\
\hline M & & Norway & Gammelelva naturreservat & TRDTR010-14 & TRD-TRI89 & \\
\hline M & & Norway & Gammelelva naturreservat & TRDTR011-14 & TRD-TRI90 & \\
\hline M & & Norway & Gammelelva naturreservat & TRDTR012-14 & TRD-TRI91 & \\
\hline $\mathrm{M}$ & & Norway & Gammelelva & TRDTR041-14 & TRD-TRI87 & \\
\hline $\mathrm{F}$ & & Norway & Genk & TRDTR113-15 & TRD-TRI190 & \\
\hline $\mathrm{F}$ & & Norway & Gammelelva & TRDTR112-15 & TRD-TRI189 & 19 \\
\hline
\end{tabular}




\begin{tabular}{|c|c|c|c|c|c|c|}
\hline$\underset{x}{\infty}$ & 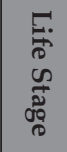 & Country & Location & $\begin{array}{l}\text { BOLD } \\
\text { Sequence ID }\end{array}$ & Specimen ID & $\begin{array}{l}\text { No. } \\
\text { haplotyp }\end{array}$ \\
\hline \multirow[t]{3}{*}{ M } & & Latvia & river Gauja & TRIFI456-11 & JSlk-20110108 & 20 \\
\hline & $\mathrm{L}$ & Finland & Loeyttynsuo lampi & TRIFI842-13 & ARin-2012F312 & 21 \\
\hline & $\mathrm{L}$ & Finland & Virkkala & TRIFI844-13 & ARin-2012F314 & 22 \\
\hline M & & Finland & Loeyttynsuo lampi & TRIFI864-13 & ARin-2012F334 & 23 \\
\hline \multicolumn{7}{|c|}{ Hagenella clathrate Kolenati, 1848} \\
\hline & A & Germany & $\begin{array}{l}\text { Bodenwoehr, Breitenbrucker } \\
\text { Weiher }\end{array}$ & FBNE176-13 & BC ZSM NEU 176 & \multirow{3}{*}{24} \\
\hline & & Germany & Ueberacker & GBEPT332-14 & GBOL03362 & \\
\hline & & Germany & Ueberacker & GBEPT334-14 & GBOL03364 & \\
\hline M & & Austria & Bizauer Moos/Bach daneben & INTAP167-17 & PE194 & 25 \\
\hline \multirow[t]{2}{*}{$\mathrm{M}$} & & Finland & Ahamsuonlampi & TRIFI584-11 & JSlk-2011F044 & 26 \\
\hline & $\mathrm{L}$ & Finland & Tappunen & TRIFI826-12 & ARin-2012F291 & 27 \\
\hline M & & Germany & $\begin{array}{l}\text { Erlenbruch im Leutstettener } \\
\text { Moos, } 400 \mathrm{~m} \text { N Heimaths }\end{array}$ & FBAQU1220-12 & BCZSMAQU00935 & 28 \\
\hline M & & Germany & $\begin{array}{l}\text { Grabenartiger Bach zum } \\
\text { Randlagg/Bruchwald S } \\
\text { Knuepp }\end{array}$ & FBCAD059-10 & BC ZSM AQU 00629 & 29 \\
\hline M & & Norway & Tormajavri & FINNT031-12 & FinnCAD-041 & 30 \\
\hline \multirow[t]{2}{*}{$\mathrm{F}$} & & Estonia & Nomme & TRIFI750-12 & JSlk-2012F215 & 31 \\
\hline & $\mathrm{L}$ & Finland & Jeesioenjoki & TRIFI822-12 & ARin-2012F287 & 32 \\
\hline \multicolumn{7}{|c|}{ Phryganea bipunctata Retzius, 1783} \\
\hline $\mathrm{F}$ & & Germany & \begin{tabular}{|l} 
Tegernsee, Ufer unterhalb \\
Kaltenbrunn (Gde. Gmund)
\end{tabular} & FBAQU273-09 & BC ZSM AQU 00273 & 33 \\
\hline M & & $\begin{array}{l}\text { Czech } \\
\text { Republic }\end{array}$ & Plesne jezero & BHMKK170-12 & HMCAD1211-170 & \multirow{4}{*}{34} \\
\hline M & & Austria & $\begin{array}{l}\text { A-Salzburg, St. Georgen, } \\
\text { Waidmoos }\end{array}$ & HMCAD322-08 & 07HMCAD-0322 & \\
\hline \multirow[t]{3}{*}{$\mathrm{M}$} & & Austria & $\begin{array}{l}\text { A-Salzburg, St. Georgen, } \\
\text { Waidmoos }\end{array}$ & HMCAD323-08 & 07HMCAD-0323 & \\
\hline & A & Austria & Kogelsbach & HMCAD331-08 & 07HMCAD-0331 & \\
\hline & & Norway & Morstadstolen & KKCAD550-09 & GGCAD909-06 & 35 \\
\hline M & & Norway & Storaastjoenna & TRDTR068-14 & TRD-TRI145 & \multirow{3}{*}{36} \\
\hline M & & Norway & Dam ved Engelsaastroea & TRDTR069-14 & TRD-TRI146 & \\
\hline M & & Norway & Store Skeistjern & TRDTR158-15 & TRD-TRI235 & \\
\hline M & & Norway & Store Skeistjern & TRDTR155-15 & TRD-TRI232 & \multirow{2}{*}{37} \\
\hline M & & Norway & Store Skeistjern & TRDTR157-15 & TRD-TRI234 & \\
\hline \multirow[t]{3}{*}{$\mathrm{F}$} & & Norway & Aasen & TRDTR156-15 & TRD-TRI233 & 38 \\
\hline & $\mathrm{L}$ & Finland & Jeesioejoki & TRIFI277-11 & JSIk-20100117 & 39 \\
\hline & $\mathrm{L}$ & Finland & & TRIFI305-11 & ARin-20100151 & 40 \\
\hline M & & Finland & Ahmasuonlampi & TRIFI487-11 & JSlk-20110139 & 41 \\
\hline
\end{tabular}




\begin{tabular}{|c|c|c|c|c|c|c|}
\hline$\underset{\mathbb{x}}{\infty}$ & 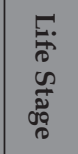 & Country & Location & $\begin{array}{l}\text { BOLD } \\
\text { Sequence ID }\end{array}$ & Specimen ID & $\begin{array}{l}\text { No. } \\
\text { haplotyp }\end{array}$ \\
\hline \multicolumn{7}{|c|}{ Phryganea grandis Linnaeus, 1758} \\
\hline M & adult & Croatia & $\begin{array}{l}\text { River Dunav near Zlatna } \\
\text { greda }\end{array}$ & CROAA134-18 & TPGRA_1 & \multirow{12}{*}{42} \\
\hline & A & Finland & Bagaskaer & COLFH083-14 & MM24011 & \\
\hline $\mathrm{F}$ & & Germany & $\begin{array}{l}\text { Donauaue } 350 \mathrm{~m} \mathrm{~W} \text { Giesenau, } \\
\text { Donau Fkm 2436,125 [rec } \\
\end{array}$ & FBAQU1224-12 & BCZSMAQU00939 & \\
\hline M & & Germany & $\begin{array}{l}\text { Grosser Ostersee, Suedufer } \\
\text { bei Mdg. Verbindungsbac } \\
\end{array}$ & FBAQU274-09 & BC ZSM AQU 00274 & \\
\hline $\mathrm{F}$ & & Germany & $\begin{array}{l}\text { Tegernsee, Ufer unterhalb } \\
\text { Kaltenbrunn (Gde. Gmund) }\end{array}$ & FBAQU275-09 & BC ZSM AQU 00275 & \\
\hline & $\mathrm{L}$ & Belgium & Geel & TFLAN036-11 & UA-SG-TRICH-NA53 & \\
\hline & $\mathrm{L}$ & Belgium & Geel & TFLAN037-11 & UA-SG-TRICH-NA54 & \\
\hline & $\mathrm{L}$ & Belgium & Mol & TFLAN116-11 & UA-SG-TRICH-NA52 & \\
\hline & $\mathrm{L}$ & Belgium & Knokke-Heist & TFLAN124-11 & UA-SG-TRICH-D77 & \\
\hline & L & Belgium & Kasterlee & TFLAN140-11 & UA-SG-TRICH-D79 & \\
\hline & $\mathrm{L}$ & Belgium & Ekeren & TFLAN279-11 & UA-SG-TRICH-X32 & \\
\hline & A & Norway & Rambjora & ZMBN036-15 & Kurs2015-SR2 & \\
\hline & & & & GBMIN35667-13 & FN600940 & 43 \\
\hline & A & Austria & St. Konrad - Hausern & HMКKT280-10 & 10HMCAD-280 & 44 \\
\hline M & & Austria & Mayrgraben, Lunz am See & HMTRI041-08 & 08HMCAD-041 & 45 \\
\hline $\mathrm{F}$ & & Austria & Salzburg, Astenschmeide & HMTRI254-09 & 08HMCAD-254 & 46 \\
\hline & $\mathrm{L}$ & Belgium & Ranst & TFLAN028-11 & UA-SG-TRICH-B42 & 47 \\
\hline & $\mathrm{L}$ & Belgium & Kortrijk & TFLAN130-11 & UA-SG-TRICH-D78 & 48 \\
\hline M & & Finland & Siikalahti & TRIFI480-11 & JSlk-20110132 & 49 \\
\hline M & & Finland & Siikalahti & TRIFI481-11 & JSlk-20110133 & 50 \\
\hline \multicolumn{7}{|c|}{ Phryganea grandis rotundata G Ulmer, 1905} \\
\hline M & & Mongolia & Arhangay, Ogiy nuur & MGCAD523-09 & ID-10340 & 51 \\
\hline M & & Mongolia & Arhangay, Ogiy nuur & MGCAD524-09 & ID-10341 & 52 \\
\hline M & & Mongolia & Arhangay, Ogiy nuur & MGCAD525-09 & ID-10342 & 53 \\
\hline M & & Mongolia & Arhangay, Ogiy nuur & MGCAD526-09 & ID-10343 & \multirow{2}{*}{54} \\
\hline M & & Mongolia & Arhangay, Ogiy nuur & MGCAD527-09 & ID-10344 & \\
\hline \multicolumn{7}{|c|}{ Lepidostoma hirtum (Fabricius, 1775) } \\
\hline M & & Croatia & River Kupa, near Pribanjci & CROAA126-18 & TLHIT_1 & 55 \\
\hline
\end{tabular}


